\title{
PENGARUH MODEL PEMBELAJARAN INQUIRY TRAINING TERHADAP HASIL BELAJAR SISWA PADA MATERI SUHU DAN KALOR DI KELAS X SMA SWASTA RK BINTANG TIMUR P. SIANTAR
}

\author{
Sri Erliani Gurning ${ }^{1)}$, Rahmatsyah ${ }^{2)}$ \\ ${ }^{1,2)}$ Pendidikan Fisika Universitas Negeri Medan \\ e-mail: sri.erliani123@gmail.com \\ rahmatunimed@gmail.com
}

\begin{abstract}
Abstrak
Telah dilakukan penelitian Pengaruh Model Pembelajaran Inquiry Training Terhadap Hasil Belajar Siswa pada materi suhu dan kalor di Kelas X Semester II SMA Swasta RK Bintang Timur P. Siantar Sumatera Utara T.P 2016/2017, dengan tujuan untuk mengetahui hasil belajar siswa menggunakan model pembelajaran Inquiry Training dan pembelajaran konvensional. Jenis penelitian adalah quasi experiment, dan pengambilan sampel dilakukan secara simple random sampling. Populasi dari penelitian ini adalah seluruh siswa kelas X. Instrumen yang digunakan yaitu tes hasil belajar kognitif dan tes keterampilan proses sains siswa. Dari analisa data untuk hasil belajar kelas eksperimen diperoleh rata-rata pretest 42,00 dan postest 78,20. Kelas kontrol diperoleh rata-rata pretest 37,64 dan postest 69,75. Analisa data untuk keterampilan proses sains kelas eksperimen diperoleh rata-rata pretest 36,54 dan postest 71,56 . Keterampilan proses sains kelas kontrol diperoleh rata-rata pretest 35,02 dan postest 63,89. Hasil analisis data menggunakan uji t satu pihak menunjukkan bahwa terdapat pengaruh model pembelajaran Inquiry Training terhadap hasil belajar siswa pada materi pokok suhu dan kalor.
\end{abstract}

Kata kunci: inquiry training, hasil belajar, suhu dan kalor.

\begin{abstract}
The research has been done Influence of Learning Inquiry Training Model to Student Learning Result on Temperature and Heat Material In Class X Semester II at Private High School RK Bintang Timur P.Siantar Sumatera Utara academic year 2016/2017, with the aim to know the result of student learning using Inquiry Training model and conventional learning. The type of research is quasi experiment, and sampling is done by simple random sampling. The population of this study is all students of class $X$. The instrument used is the test of cognitive learning outcomes and tests students' science process skills. From the data analysis for the experimental class learning results obtained the average pretest 42.00 and postest 78.20. The control class was obtained on average pretest 37,64 and postest 69,75. From the data analysis for experimental science process class skill obtained the average of pretest 36,54 and posttest 71,56. The control class was obtained on average pretest 35.02 and postest 63.89. The result of data analysis using independent sample t test shows that there is influence of instructional model of Inquiry Training on student learning outcomes on the subject matter of temperature and heat.
\end{abstract}

Keywords: inquiry training, learning outcomes, temperature and heat 


\section{Pendahuluan}

Pendidikan adalah usaha sadar untuk menumbuh kembangkan potensi sumber daya manusia peserta didik dengan cara mendorong dan memfasilitasi kegiatan belajar mereka. Melalui pendidikan manusia akan tumbuh dan berkembang sebagai pribadi yang utuh dan dapat bersaing di kancah internasional. Berhasilnya pembangunan di bidang pendidikan akan dapat mengangkat martabat dan nilai suatu negara (Syah, 2013).

Di zaman yang modern ini berkembangnya pendidikan berpengaruh terhadap perkembangan ilmu pengetahuan dan teknologi (IPTEK). Pesatnya perkembangan ilmu pengetahuan dan teknologi tidak terlepas dari kemajuan ilmu fisika yang ditunjukan dengan temuan baru dalam bidang sains dan teknologi.

Fisika merupakan salah satu cabang ilmu pengetahuan alam (IPA) yang mempelajari gejala-gejala alam dan interaksi di dalamnya. Pelajaran fisika lebih menekankan pada pembelajaran langsung untuk meningkatkan kompetensi agar siswa mampu berpikir kritis dan sistematis dalam memahami konsep fisika, sehingga siswa memperoleh pemahaman yang benar tentang fisika. Fisika tidak mudah diterima secara prosedural tanpa pemahaman dan penalaran. Pengetahuan tidak dapat dipindahkan begitu saja dari otak seseorang (guru) ke fikiran orang lain (siswa). Siswa sendiri yang harus mengartikan apa yang telah diajarkan dengan menyesuaikan terhadap pengalaman sehari-hari. Faktor penting dalam keberhasilan pencapaian tujuan pendidikan adalah faktor guru. Sebagai fasilitator, guru berperan untuk memudahkan siswa dalam kegiatan proses belajar (Sanjaya, 2013).

Proses pembelajaran pada anak kurang didorong untuk mengembangkan kemampuan berpikir. Proses pembelajaran di dalam kelas diarahkan kepada kemampuan anak untuk menghafal informasi, otak anak dipaksa untuk mengingat dan menimbun berbagai informasi tanpa dituntut untuk memahami informasi yang diingatnya itu untuk menghubungkannya dengan kehidupan sehari-hari. Pembelajaran menjadi bermakna bagi siswa, jika guru bisa memberikan keterampilan-keterampilan tertentu dalam kegiatan pembelajaran fisika. Salah satu keterampilan dalam pembelajaran fisika adalah keterampilan proses sains (KPS) (Sanjaya, 2013).

Berdasarkan angket yang dibagikan pengkaji di SMA Swasta RK Bintang Timur P. Siantar, menunjukkan bahwa fisika merupakan salah satu mata pelajaran yang kurang digemari siswa. Pelajaran fisika dianggap kurang menyenangkan dan banyak rumus. Dari 97 siswa, terdapat 43,29\% kurang menggemari fisika, 30,08\% menggemari pelajaran lainnya, dan hanya $20,61 \%$ saja yang menggemari fisika. Siswa beranggapan bahwa pelajaran fisika sulit, rumit, dan banyak rumusnya, sehingga siswa lebih dahulu merasa takut dan jenuh sebelum mempelajarinya. Salah satu faktor yang menyebabkan siswa tidak menggemari pelajaran fisika adalah model pembelajaran yang digunakan oleh guru kurang bervariasi, sehingga kurang menarik minat siswa untuk belajar fisika. Guru masih menggunakan metode ceramah. Fisika lebih banyak mencatat dan memberi contoh soal tetapi kurang praktikum. Dengan kata lain proses pembelajaran fisika masih cenderung berbasis hafalan teori, konsep-konsep dan rumus serta tidak didasarkan pada pengalaman siswa, guru tidak menilai KPS siswa karena instrumen yang digunakan guru belum menuju pada KPS siswa. KPS siswa tidak dapat diajarkan hanya dengan menggunakan metode ceramah. Adanya permasalahan-permasalahan dalam pembelajaran dapat mempengaruhi hasil belajar siswa pada mata pelajaran fisika.

Mengatasi masalah tersebut, perlu diupayakan pemecahannya. Salah satu di antaranya yaitu menggunakan model pembelajaran yang lebih efektif dan variatif serta disesuaikan dengan kondisi dan situasi belajar yang dapat menumbuhkan minat dan motivasi siswa dalam belajar fisika. Salah satu cara yang dapat digunakan untuk mengatasi masalah tersebut adalah dengan model pembelajaran Inquiry Training.

Model pembelajaran Inquiry Training dirancang untuk membawa siswa secara langsung ke dalam keterampilan proses ilmiah melalui latihan-latihan yang dapat memadatkan proses ilmiah tersebut ke dalam periode waktu yang singkat (Joyce, 2009). 


\section{Bahan dan Metode}

Jenis penelitian ini termasuk penelitian quasi eksperimen, yaitu merupakan penelitian yang bertujuan untuk mengetahui ada tidaknya perbedaan akibat pengaruh dari "sesuatu" yang dikenakan pada subyek penelitian yaitu siswa.

Penelitian ini dilaksanakan di SMA Swasta RK Bintang Timur P. Siantar. Waktu penelitian dimulai pada bulan April 2017 sampai Mei 2017 pada tahun ajaran 2016/2017.

Populasi dalam penelitian ini adalah seluruh siswa kelas X semester. Sampel dalam penelitian terdiri dari dua kelas yaitu kelas kontrol dan kelas eksperimen yang diambil dengan teknik simple random sampling. Kelas eksperimen diterapkan model pembelajaran Inquiry Training dan kelas kontrol menggunakan pembelajaran konvensional.

Instrumen yang digunakan untuk mengumpulkan data hasil belajar siswa sebelum dan sesudah pembelajaran model Inquiry Training adalah tes hasil belajar kognitif dan tes keterampilan proses sains pada materi suhu dan kalor berupa test uraian yang berjumlah 7 soal dan tes keterampilan proses sains yang berjumlah 5 soal.

Dari hasil pretest masing-masing instrumen yang diperoleh dilakukan uji normalitas dengan menggunakan uji Lilliefors, uji homogenitas dengan menggunakan uji kesamaan varians dan uji kesamaan rata-rata (uji-t dua pihak) untuk menentukan apakah data berdistribusi normal, homogen, dan tidak ada perbedaan yang signifikan antara hasil belajar kedua kelas. Selanjutnya kedua kelas diberi perlakuan yang berbeda, kelas eksperimen diberi perlakuan dengan menggunakan model pembelajaran Inquiry Training dan kelas kontrol diberi perlakuan dengan menggunakan model pembelajaran konvensional. Setelah itu kedua kelas diberi postest. Dari hasil postest masing-masing instrumen yang diperoleh dilakukan kembali uji normalitas, homogenitas dan uji kesamaan rata-rata (uji-t satu pihak) untuk menentukan apakah data hasil belajar siswa tergolong normal, homogen, dan ada perbedaan hasil belajar kedua antara kelas akibat pengaruh model pembelajaran Inquiry Training terhadap hasil belajar siswa.
Adapun tahapan pelaksanaan penelitian digambarkan dalam bentuk diagram alur seperti ditunjukkan Gambar 1 berikut.

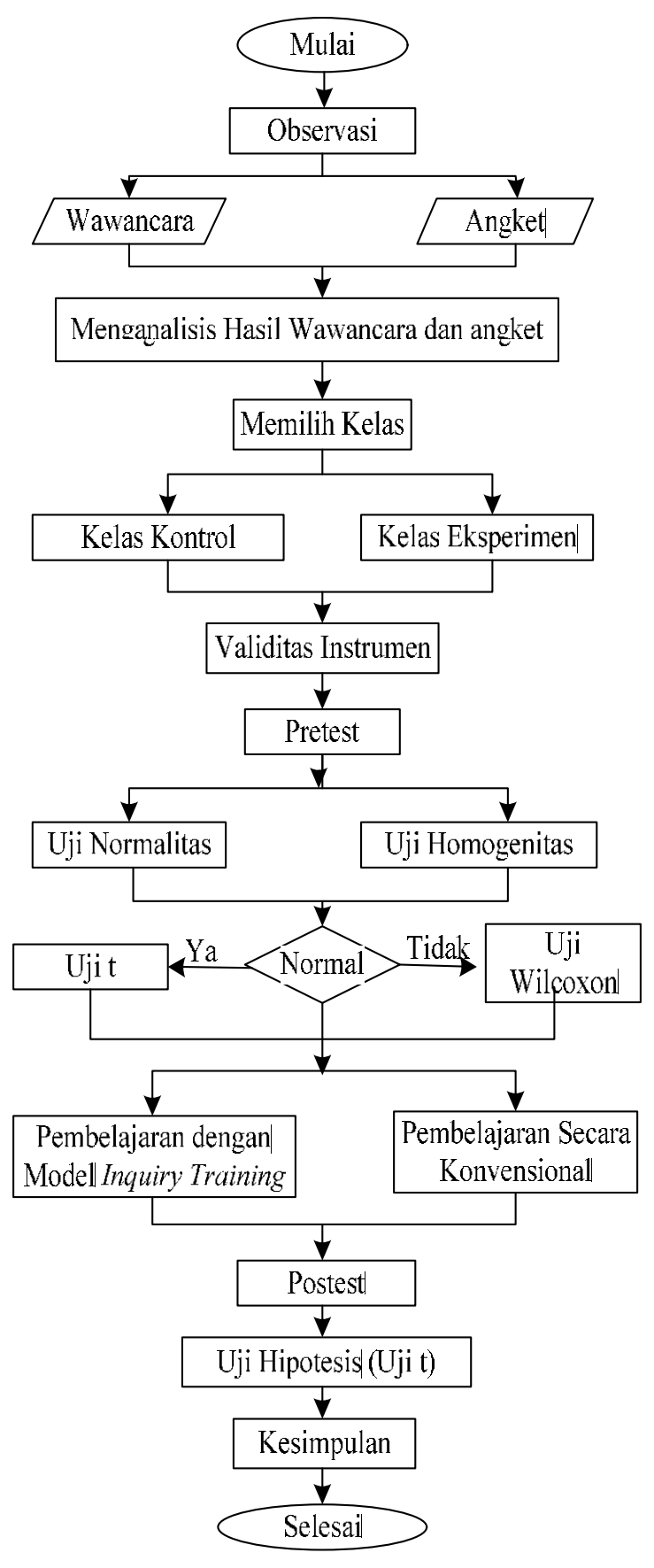

Gambar 1. Rancangan penelitian.

\section{Hasil dan Pembahasan}

Data dari hasil penelitian berupa hasil belajar kognitif dan KPS siswa pada pretest dan postest masing-masing instrumen. 
Perolehan nilai rata-rata pretest hasil belajar siswa di kelas kontrol sebesar 37,64 dan nilai rata-rata postest sebesar 69,75 sedangkan di kelas eksperimen diperoleh nilai rata-rata pretest 42,00 dan nilai rata-rata postest 78,20. Perolehan nilai rata-rata pretest keterampilan proses sains siswa di kelas kontrol sebesar 35,02 dan nilai rata-rata postest sebesar 63,89, sedangkan di kelas eksperimen diperoleh nilai rata-rata pretest 36,54 dan nilai rata-rata postest 71,56 .

Hasil uji normalitas terhadap hasil belajar dan keterampilan proses sains untuk kedua sampel diperoleh bahwa nilai pretest berdistribusi normal dimana $\mathrm{L}_{\text {hitung tidak }}$ melebihi $\mathrm{L}_{\text {tabel }}$ dan berasal dari populasi yang homogen. Hasil perhitungan uji kesamaan nilai rata-rata pretest KPS kelas eskperimen dan kelas kontrol, diperoleh $\mathrm{t}_{\text {hitung }}<\mathrm{t}_{\text {tabel }}(0,47<$ 1,99) dan hasil perhitungan uji kesamaan nilai rata-rata pretest hasil belajar, diperoleh $\mathrm{t}_{\text {hitung }}<$ $t_{\text {tabel }}(1,35<1,99)$ yang berarti bahwa tidak terdapat perbedaan yang signifikan sehingga penelitian dengan menerapkan model pembelajaran Inquiry Training dapat dilakukan.

Tabel 1. Data pretest hasil belajar siswa

\begin{tabular}{cccccccccc}
\hline \multirow{2}{*}{ No } & $\begin{array}{c}\text { Interval } \\
\text { Nilai }\end{array}$ & \multicolumn{3}{c}{ Kelas Eksperimen } & $\mathbf{5}$ & \multicolumn{3}{c}{ Kelas Kontrol } \\
\cline { 2 - 9 } & $\mathbf{f}$ & $\overline{\boldsymbol{X}}$ & $\mathbf{S}^{2}$ & $\mathbf{S}$ & $\mathbf{f}$ & $\overline{\boldsymbol{X}}$ & $\mathbf{S}^{2}$ & $\mathbf{S}$ \\
\hline 1 & $15-24$ & 5 & & & & 9 & & & \\
2 & $25-34$ & 6 & & & & 10 & & & \\
3 & $35-44$ & 8 & & & & 7 & & & \\
4 & $45-54$ & 13 & 42,00 & 201,38 & 14,19 & 5 & 37,64 & 227,73 & 15,09 \\
5 & $55-64$ & 3 & & & & 4 & & & \\
6 & $65-74$ & 2 & & & & 2 & & & \\
\hline Jumlah & 37 & & & 37 & & \\
\hline
\end{tabular}

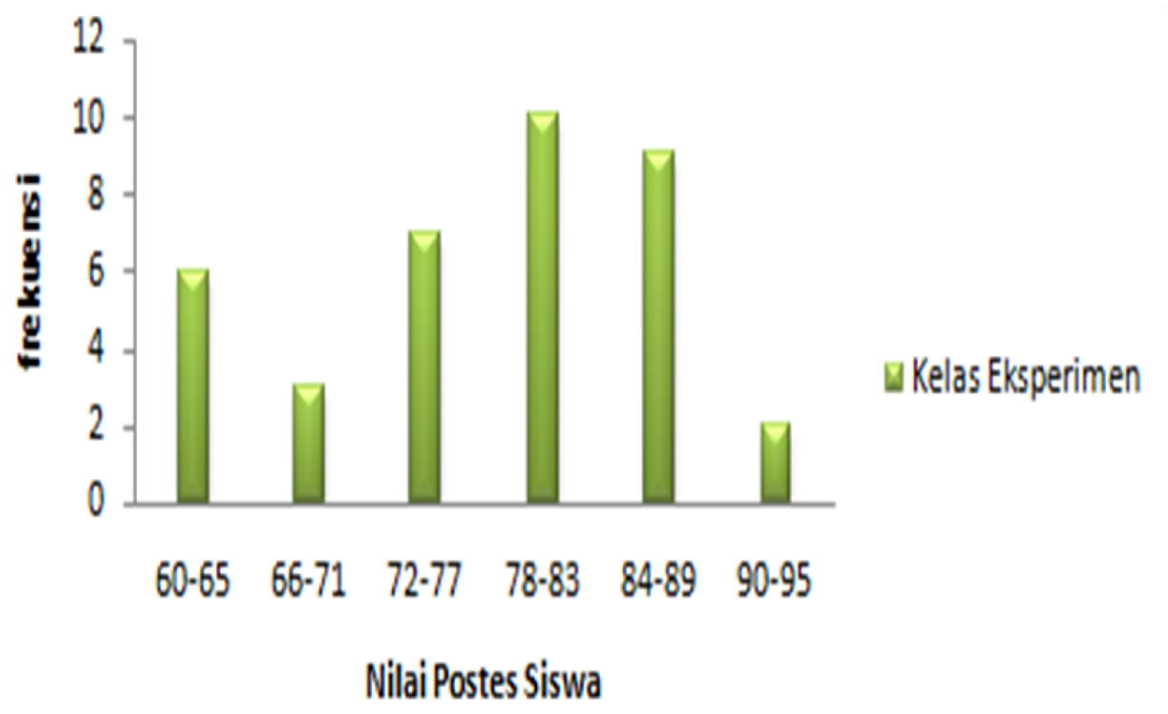

Gambar 2. Diagram batang nilai postest hasil belajar kelas eksperimen. 


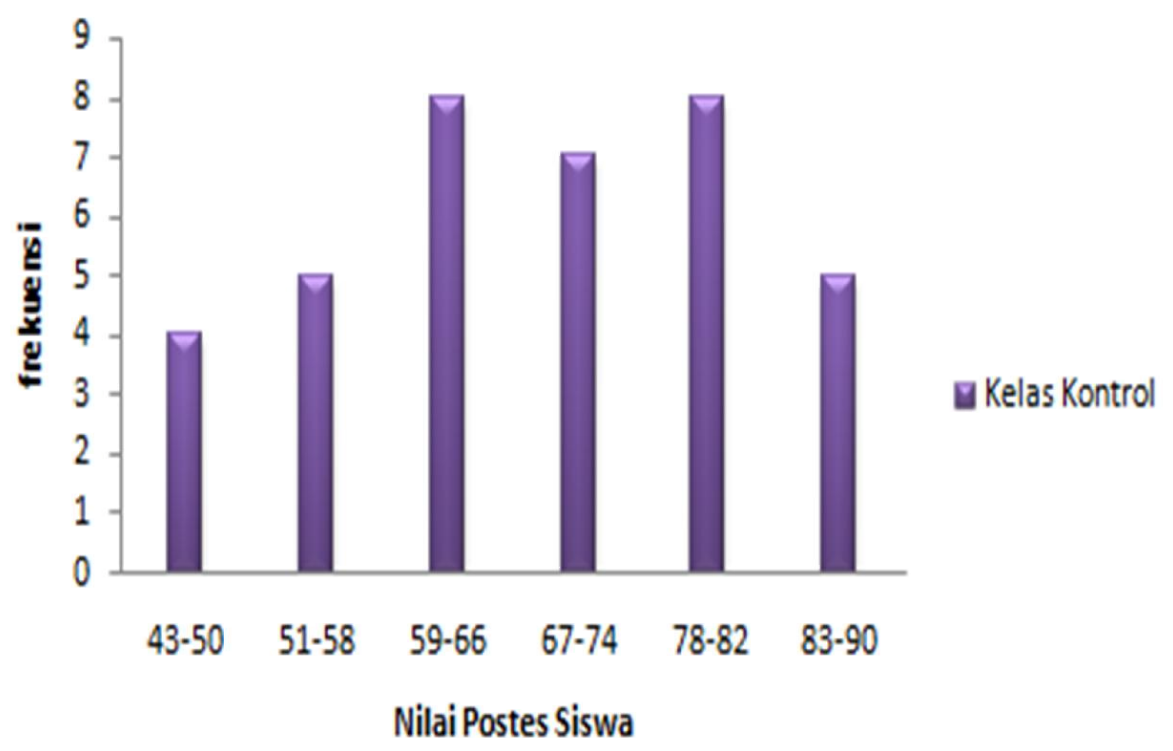

Gambar 3. Diagram batang nilai postest hasil belajar kelas kontrol.

Tabel 2 Data pretest KPS

\begin{tabular}{cccccccccc}
\hline \multirow{2}{*}{ No } & Interval & \multicolumn{3}{c}{ Kelas Eksperimen } & \multicolumn{5}{c}{ Kelas Kontrol } \\
\cline { 2 - 9 } & Nilai & $\mathbf{F}$ & $\overline{\boldsymbol{X}}$ & $\mathbf{S}^{\mathbf{2}}$ & $\mathbf{S}$ & $\mathbf{f}$ & $\overline{\boldsymbol{X}}$ & $\mathbf{S}^{\mathbf{2}}$ & $\mathbf{S}$ \\
\hline 1 & $15-24$ & 10 & & & & 9 & & & \\
2 & $25-34$ & 12 & & & & 11 & & & \\
3 & $35-44$ & 7 & & & & 8 & & & \\
4 & $45-54$ & 4 & 36,54 & 236,64 & 15,38 & 6 & 35,02 & 187,80 & 13,70 \\
5 & $55-64$ & 4 & & & & 2 & & & \\
6 & $65-74$ & 2 & & & & 1 & & & \\
\hline \multicolumn{2}{l}{ Jumlah } & 37 & & & & 37 & & & \\
\hline
\end{tabular}

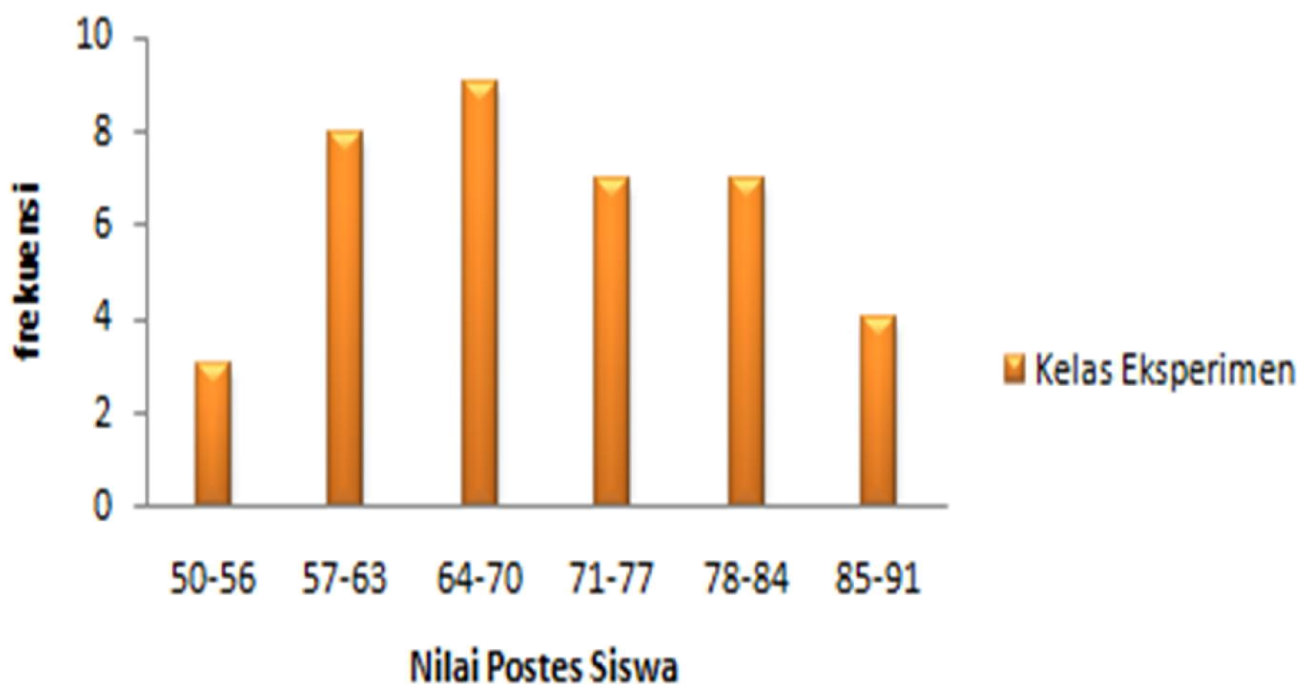

Gambar 4. Diagram batang nilai postest KPS kelas eksperimen. 


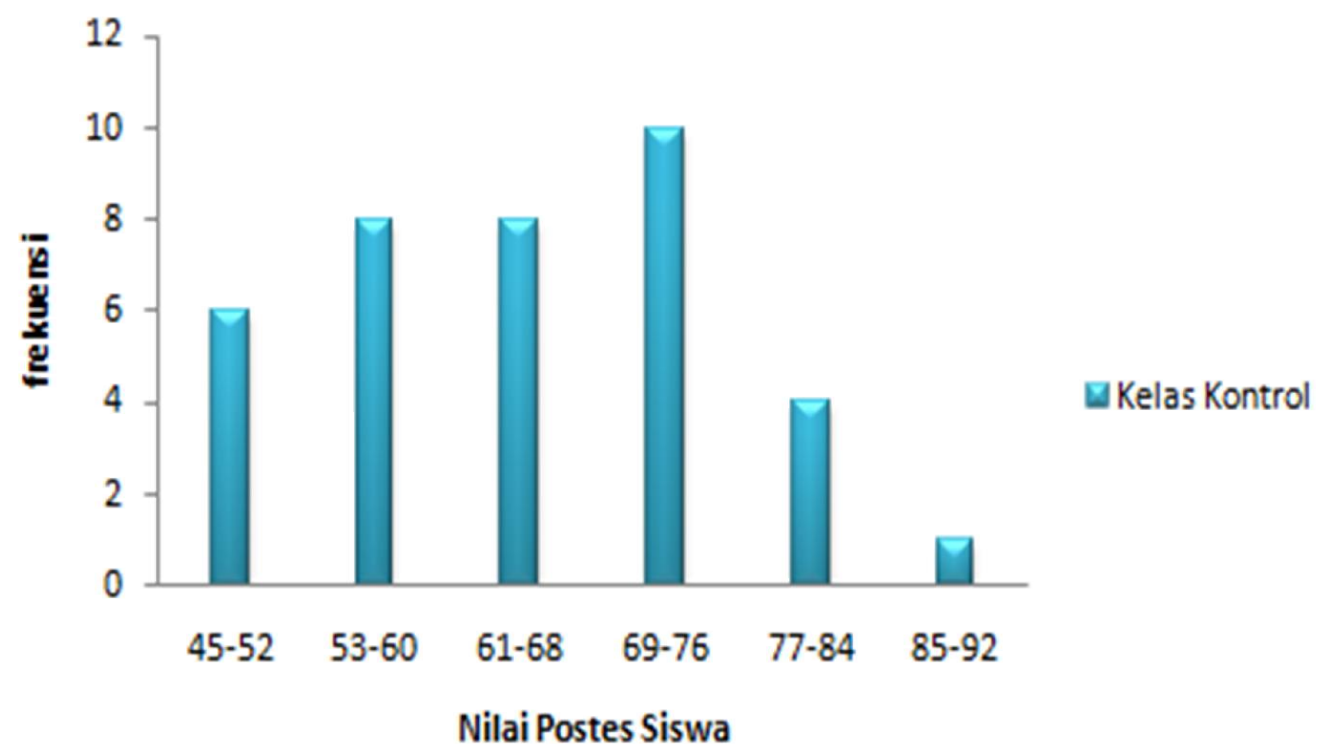

Gambar 5. Diagram batang nilai postest KPS kelas kontrol.

Hasil uji hipotesis postest hasil belajar menggunakan uji t pada taraf signifikan $\alpha=$ 0,05 diperoleh $t_{\text {hitung }}>t_{\text {tabel }}(3,43>1,66)$ dan hasil uji hipotesis keterampilan proses sains menggunakan uji $\mathrm{t}$ pada taraf $\alpha=0,05$, diperoleh $t_{\text {hitung }}>t_{\text {tabel }}(3,04>1,66)$ yang berarti bahwa terdapat perbedaan hasil belajar siswa yang signifikan menggunakan model pembelajaran Inqury Training dengan model pembelajaran konvensional.

Hasil penelitian ini menyatakan bahwa hasil belajar fisika dengan menggunakan model Inquiry Training lebih tinggi daripada model pembelajaran konvensional. Hal ini sejalan dengan penelitian terdahulu seperti yang diteliti oleh Pandey et al. (2011) menyatakan dengan menggunakan model pembelajaran Inquiry Training memberikan efek yang lebih signifikan daripada metode pembelajaran konvensional terhadap hasil belajar siswa. Hal ini sejalan juga dengan penelitian Purwanto \& Arini Ulfah Mawaddah (2015) terkait pengaruh model pembelajaran Inquiry Training terhadap hasil belajar fisika siswa, menyatakan bahwa hasil belajar siswa menggunakan model Inquiry Training dengan hasil postest 75,76 lebih baik dibandingkan dengan pembelajaran konvensional dengan hasil postestnya senilai 70,53 . Hasil penelitian Simamora dan Arisa (2014), juga mengatakan bahwa hasil belajar siswa lebih baik dengan menggunakan model pembelajaran Inquiry
Training terhadap hasil belajar siswa pada materi pokok Fluida Statis. Dengan demikian Penerapan pembelajaran Inquiry Training dapat memberikan pengaruh peningkatan hasil belajar siswa dan keterampiran proses sains (KPS) siswa dalam mempelajari materi suhu dan kalor.

\section{Kesimpulan dan Saran}

Berdasarkan hasil penelitian yang diperoleh maka dapat disimpulkan: hasil belajar fisika siswa dan keterampilan proses sains siswa dengan menggunakan model pembelajaran Inquiry Training memberikan nilai rata-rata 78,20 dan 71,56 . Hasil belajar siswa dan keterampilan proses sains dengan menggunakan pembelajaran konvensional memberikan nilai rata-rata 69,75 dan 63,89 . Terdapat perbedaan yang signifikan akibat pengaruh model pembelajaran Inquiry Training terhadap hasil belajar siswa pada materi pokok suhu dan kalor.

Untuk peneliti selanjutnya dapat menggunakan model pembelajaran Inquiry Training dengan penerapan yang lebih optimal melalui penambahan media pembelajaran yang sesuai. 


\section{Daftar Pustaka}

Joyce, B., Weil, M., \& Calhoun, E., 2009. Model-Model Pembelajaran. Edisi Delapan, Pustaka Belajar, Yogyakarta.

Pandey, A., Nanda. G.K., \& Ranjan, V., 2011. Effectiveness of Inquiry Training Model over Conventional Teaching Method on Academic Achievement of Science Students in India. Journal of Innovative Research in Education,1(1), 7-20.

Purwanto \& Arini, M., 2015. Pengaruh Model Pembelajaran Inquiry Training terhadap
Hasil Belajar Fisika Siswa. Jurnal Pendidikan Fisika.

Sanjaya, W., 2013. Srategi Pembelajaran Berorientasi Standar Proses Pendidikan. Kencana, Jakarta.

Simamora, P. \& Arisa, Y., 2014. Pengaruh Model Pembelajaran Inquiry Training terhadap Hasil Belajar Siswa pada Materi Pokok Fluida Statis. Jurnal Pendidikan Fisika.

Sudjana, 2005. Metode Statistika. Tarsito, Bandung.

Syah, Muhibbin, 2003. Psikologi Belajar. Rajawali Pers, Bandung. 